\title{
References
}

1) DeSouza, E. J. and Kothare, S. N. J. Histochem. Cytochem. 7, 77, $1959 . \quad$ 2) Quaglino, D. and Hayhoe, F. G. J. Nature 187, 85, $1960 . \quad 3$ 3) Fishman, W. H., Ladue, K. T. and Borges, P. R. F. J. Histochem. Cytochem. 9, 424, 1961 . 4) Morrison, J. H. and Kronheim. S. J. Histochem. Cytochem. 10, 402, $1962 . \quad$ 5) Nachlas, M. M., Tsou, K-C., DeSouza, E., Cheng, C-S. and Seligman, A. M. J. Histochem. Cytochem. 5, 420, 1957.6 6) Wattenberg, L. W. J. Histochem. Cytochem. 6, 225, 1958.7 7) Wattenberg, L. W. and Leong, J. L. J. Histochem. Cytochem. 8, 296, 1960.8 8) Shelton, E. and Schneider, W. C. Anat. Rec. 112, 61, 1952.99$)$ Racker, E. Physiol. Rev. 35, 1, 1955.110$)$ Zimmermann, H. and Pearse, A. G. E. J. Histochem. Cytochem. 7, 271, 1959 . 11) Mizutani, A., Hikima, K. and Takamatsu, H. Proc. Jap. Histochem. Ass. 1, 66, 1960 . 12) Mizutani, A. and Hikima, K. Acta Tuberc. Jap. 11(1), 17, $1961 . \quad$ 13) Pearse, A. G. E. Histochemistry. Theoretical and Applied. London, J. \& A. Churchill, Ltd., 2nd edition, 1960.14 14) Novikoff, A. B., Shin, W-Y. and Drucker, J. J. Biophys. Biochem. Cytol. 9, 47, 1961. 15) Novikoff, A. B., Shin, W-Y. and Drucker, J. J. Histochem. Cytochem. 8, 37, 1960.116$)$ Chang, J. P. and Hori, S. H. J. Histochem. Cytochem. 9, 292, 1961.

\section{Explanation of plates}

All photomicrographs show DPN-diaphorase reaction of Ehrlich ascites tumor cells.

Fig. 1. Unfixed cells; formazan granules are coarse. $\times 1000$.

Fig. 2, and 3. Cold acetone fixation; cell morphology is well preserved and most of the cells show the homogeneous staining in the cytoplasm. $\times 1000$.

Fig. 4. Formaldehyde vapor fixation; fine granular localization of formazans are distinctive in the cytoplasm (arrow). $\times 1000$.

\section{Histochemical Study on Various Dehydrogenases of Normal Epithelium of Portio Vaginalis and Squamous Cell Carcinoma of Human Uterine Cervix}

\author{
Naotaka Ishizuka M. D., Minoru IshinARA M. D. \\ and Gen Hasegawa M. D.
}

The Department of Obst. \& Gynec,. School of Medicine Nagoya University, Nagoya

Recently the nitroblue tetrazolium is well known as an useful indicator dye for the histochemical demonstration of dehydrogenase in tissue $(1,2,3)$. The distributions of 3 dehydrogenase systems, consisting of succinate dehydrogenase; DPN-linked dehydrogenases responsible for the oxidation of lactate, malate, $\alpha$-glycerophosphate, glutamate and $\beta$-hydroxybutyrate; TPN-linked 
dehydrogenases responsible for the oxidation of glucose-6-phosphate and isocitrate, were comparatively survived between normal epithelium of portio vaginails and squamous cell carcinoma of human uterine cervix by application of nitro $\mathrm{BT}$ technique $(4,5,6,7)$. This study is one of the enzymic histochemical investigations on malignant tumors in our clinic.

\section{Materials and Methods}

Materials were obtained exclusively from surgical specimens, and were frozen immediately on a block of dry ice. We studied on 36 squamous cell carcinomas and 10 normal tissues, obtained from mature or climacteric or postmenopausal women.

The block was cut in a cryostat into fresh-frozen sections of 15 to 20 microns, which were dried in air at room temperature for a short period of time ( 5 to 10 minutes), put on slides and were incubated in the each mediums (table 1) for 30 minutes at $37^{\circ} \mathrm{C}$. Parallel sections were stained with hematoxylin eosin.

Result 1 (table 2)

Table 1 Mediums

\begin{tabular}{l|c|c|c}
\multicolumn{1}{|c|}{ Substrate } & Coenzyme & Buffer Solution & pH \\
\hline Sod. Succinate & - & Phosphate Buffer & 7.4 \\
Sod. Lactate & DPN & Phosphate Buffer & 7.4 \\
Sod. Malate & DPN & Phosphate Buffer & 7.4 \\
Sod. $\alpha$-Glycerophosphate & DPN & Phosphate Buffer & 7.4 \\
Sod. Glutamate & DPN & Phosphate Buffer & 7.6 \\
Sod. $\beta$-Hydroxybutyrate & DPN & Phosphate Buffer & 7.6 \\
Sod. Glucose-6-phosphate & TPN & Veronal Buffer & 7.4 \\
Sod. Isocitrate & TPN & Veronal Buffer & 7.4 \\
\hline
\end{tabular}

Succinate dehydrogenase activity was remarkable in the basal layer of normal epithelium and rapidly decreased as cornification proceeds. Lactate dehydrogenase revealed remarkable activity in the all layers of epithelum except the cornified layer. Malate dehydrogenase was slightly less active than lactate dehydrogenase, but similarly distributed. Alpha-glycerophosphate dehydrogenase showed moderately strong activity in the basal layer and gradually decreased proceeding to cornification. Glutamate dehydrogenase activity distributed nearly as same as $\alpha$-glycerophosphate dehydrogenase. Beta-hydroxybutyrate dehydrogenase was negative in cornified layer, but it showed moderate or weak activity in the subcornified layer, on the other layer the activity was weak. Both TPN-isocitrate dehydrogenase and glucose-6-phosphate dehydrogenase activity were negative in the cornified layer and were weak in the other layer of epithelium.

Result 2 (table 2)

The squamous cell carcinomas of uterine cervix are devided into welldifferentiated, intermediately differentiated and undifferentiated form. 8 Succi- 
Table 2. Distrlbution of Succlnate Dehydrogenase and DPN-Linked Dehydrogenases and TPN-Linked Dehydrogenases in Normal Squamous Epithelium and Squamous Cell Carcinoma of Human Uterine Cervix

\begin{tabular}{|c|c|c|c|c|c|c|c|c|c|}
\hline & Dohud & & & PN-Link & ked Dehyd & drogenas & & $\begin{array}{r}\text { TPN-L } \\
\text { Dehydro }\end{array}$ & $\begin{array}{l}\text { Linked } \\
\text { ogenases }\end{array}$ \\
\hline Tis & ssue & cinate & Lactate & Malate & $\left|\begin{array}{c}\alpha-\mathrm{Gly}- \\
\text { ceropho- } \\
\text { sphate }\end{array}\right|$ & $\begin{array}{c}\text { Gluta- } \\
\text { mate }\end{array}$ & $\begin{array}{r}\beta-\text { Hyd- } \\
\text { roxybu- } \\
\text { tyrate }\end{array}$ & $\begin{array}{r}\text { Glucose } \\
-6 \text {-phos- } \\
\text { phate }\end{array}$ & $\begin{array}{l}\text { Isoci- } \\
\text { trate }\end{array}$ \\
\hline$\varepsilon$ & Stratum corneum & 0 & 0 & 0 & 0 & 0 & 0 & 0 & 0 \\
\hline$=\stackrel{\Xi}{\Xi}$ & Stratum $_{\text {granulosum }}$ & $1-2$ & 3 & $2-3$ & $1-2$ & $1-2$ & $1-3$ & $0-1$ & $0-1$ \\
\hline$\underline{E}$ & Stratum spinosum & 2 & 3 & 3 & 2 & $1-2$ & $1-2$ & 2 & 2 \\
\hline $\bar{z}$ & Stratum basale & 4 & 4 & 4 & 3 & 3 & $1-2$ & 2 & 2 \\
\hline Stro & $\begin{array}{l}\text { of } \\
\text { Normal Tissue }\end{array}$ & $0-2$ & $2-3$ & $1-3$ & $0-1$ & $0-1$ & $0-1$ & $0-1$ & $0-1$ \\
\hline $\begin{array}{l}\text { 鸮 } \\
\text { z }\end{array}$ & $\begin{array}{l}\text { Well Differen- } \\
\text { tiated Form }\end{array}$ & $0-3$ & $0-4$ & $0-3$ & $0-3$ & $0-3$ & $0-2$ & $0-2$ & $0-2$ \\
\hline 茎 & $\begin{array}{l}\text { Intermeiately } \\
\text { Diff. Form }\end{array}$ & $2-4$ & $3-4$ & $2-4$ & $2-3$ & $2-3$ & $1-2$ & $1-2$ & $1-2$ \\
\hline త్ర & $\begin{array}{l}\text { Undifferentiated } \\
\text { Form }\end{array}$ & $2-3$ & $2-4$ & $2-3$ & $1-3$ & $1-3$ & $1-2$ & $1-2$ & $1-2$ \\
\hline Stro & $\begin{array}{l}\text { ma of } \\
\text { Carcinoma Tissue }\end{array}$ & $0-2$ & $2-3$ & $1-3$ & $0-1$ & $0-1$ & $0-1$ & $0-1$ & $0-1$ \\
\hline
\end{tabular}

Activiy was graded microscopically on the basis of colour reaction in 0 to 4 by inspection.

nate dehydrogenase activity was revealed in every carcinoma nest of welldifferentiated form except its keratinous pearl. Both lactate dehydrogenase and malate dehydrogenase activity were nearly as same as succinate dehydrogenase. Other dehydrogenase activity on this study also showed moderate or weak reaction in each carcinoma nest except the keratinous pearl. While comparatively high activity was often seen in the vicinity of keratinous pearl on every dehydrogenase-reaction. Dehydrogenase activity was also revealed on the intermediately differentiated form and most marked in the peripheral layer or central portion of carcinoma nest. In the undifferentiated form dehydrogenase activity was shown, although irregularity of the distribution was found. Lactate dehydrogenase activity was remarkable in the every type of carcinoma nests, succinate dehydrogenase and malate dehydrogenase were less active than lactate dehydrogenase, and other dehydrogenases were much less active.

\section{Summary}

Thirty six squamous cell carcinomas and 10 normal tissues of human uterine cervix were histochemically studied on the 3 dehydrogenase systems ; succinate dehydrogenase, $5 \mathrm{DPN}$-dependant dehydrogenases (lactate, malate, $\alpha$-glycerophosphate, glutamate, $\beta$-hydroxybutyrate) and 2 TPN-dependent dehydrogenases (glucose-6-phosphate, isocitrate). Recently developed methods based on the use of nitro-blue tetrazolium were applied.

On the normal epithelium of portio vaginalis, succinate dehydrogenase activity was remarkably high in the basal layer. Lactate dehydrogenase and 
malate dehydrogenase activity were remarkably strong in all layers of epithelium except the cornified layer. Decreasing activity of the DPN-linked dehydrogenases were noted in the follwing order: lactate, malate, $\alpha$-glycerophospate, glutamate, $\beta$-hydroxybutyrate. And 2 TPN-linked dehydrogenases were less active than DPN-linked dehydrogenases except the $\boldsymbol{\beta}$-hydroxybutyrate dehydrogenase activity. Cornified layer of epithelium showed abundant dehydrogenase activity, on the contrary the most basal layer was remarkably reactive for all dehydrogenases on this study.

On carcinoma nest the dehydrogenase activity was negative in the keratinous pearl of well-differentiated form. It was similar to the cornified layer of normal epithelium. While the activity in the well-differentiated carcinoma nest except the keratinized portion, the intermediately differentiated and the undifferentiated form was similar or less to the activity of stratum germinativum of normal epithelium.

\title{
References
}

1) Monis, B., Nachlas, M. M., Seligman, A. M., Cancer $12: 1238-1247,1959 . \quad$ 2) Deane, H. W., Lobel, B. L., Romney, S. L., Am. J. Obst. \& Gynec. $83: 281-294,1962 . \quad 3$ 3) Lobel, B. L., Deane, H. W., Rommey, S. L., Am. J. Obst. \& Gynec. 83 : 295-299, 1962. 4) Nachlas, M. M., Tsou, K. C., De Souza, E., Cheng, C. S., Seligman, A. M., J., Histochem. 5: 420-436, 1957. 5) Nachlas, M. M., Walker, D. G., Seligman, A. M.' J. Biophys. Biochem. Cytol. $4: 29-38,1958.6$ 6) Nachlas, M. M., Walker, D. G., Seligman, A. M', J. Biophys. Biochem. Cytol. $4: 467-474,1958$. 7) Nachlas, M. M., Course in Histochemistry, June 13 to $18,26,1960$. 8) Herbut, P. A., Gynecological and Obstetrical Pathology, 219-222, 1953.

\section{Histochemical Study of $\beta$-Glucuronidase in the Uterine Cancers}

\author{
Naotaka IshizukA and Minoru IsHiHARA \\ Department of Obstrics and Gynecology Nagoya University, School of Menicine. \\ Hideo Yamada, Ginshiro Nobata and Isawo Chaya \\ Depatment of Obstrics and Gynecology Nagoya National Hospital.
}

\section{Introduction}

As the enzymatic studies of malignant tumors in the biochemical region progress, we want to know the localization of these enzymes. In the year 1934 Masamune observed $\beta$-glucurondase in the kidney of ox and in the same year Oshima observed it in many different animal tissues. In 1947 Fishman found intense activity of $\beta$-glucuronidase in cancer tissues. It has been sugge- 